\title{
A Program for Lifelong Learning During the Covid 19 Pandemic:
}

\author{
Father Accompanies Early Childhood Learning from Home
}

\author{
Eko Sulistiono* \\ Department of Community Education \\ Universitas Pendidikan Indonesia \\ Bandung, Indonesia \\ *ekosulistiono@upi.edu
}

\author{
Mustakim \\ Department of Early Childhood Islamic Education \\ Universitas Muhammadiyah Gresik \\ Geresik, Indonesia \\ mustakim@umg.ac.id
}

\author{
Deti Nudiati \\ Department of Community Education \\ Universitas Pendidikan Indonesia \\ Bandung, Indonesia \\ deti.nudiati@upi.edu
}

\begin{abstract}
Lifelong education starts from the time in the womb to the end of life. Parents during the Covid-19 pandemic became the main educators at home. Parenting patterns, child learning assistance, and informal education in the family become real experiences, which must be lived by fathers, mothers and children everyday. Currently all individuals in all parts of the world are faced with a period of global health crisis due to coronavirus (Covid 19) which has an impact on the realm of education. The pattern of implementing education changes rapidly, which requires parents to play a full role in the continuation of the early childhood learning process. This article aims to explore the views of parents, especially fathers, in providing tutoring for children during a pandemic. The method used was mixed methods research design using an explanatory sequential design approach, namely by collecting information data using qualitative and quantitative approaches. The final result of the research is the pattern of father's mentoring while at home playing three figures at once in parenting, both as educators, mentors and nurses in a socio-ecological perspective.
\end{abstract}

Keywords-lifelong learning, father's role, learning from home, covid-19

\section{INTRODUCTION}

Humans as objects in the educational process consciously need learning. The process of getting lifelong education in the era of the Covid-19 pandemic has a significant difference compared to the era before the Covid-19 pandemic. Lifelong learning is seen as a globalization phenomenon that provides space for people to learn in all aspects of life. This is marked by the name "society of signs" [1]. This concept aims to provide space for society to place lifelong learning in all aspects of life, such as cultural, social and political activities.
All education during the pandemic-covid-19 era was marked by the disclosure of information from the mass media, the government and the wider community. The public can learn about the impact of the Covid-19 pandemic for both families and others. This condition is in line with the concept of lifelong learning that (1) the learning that individuals get does not come from the individual's mind, but comes from the distribution of daily information; (2) individual learning is not a matter of mental processes, but what is embedded in individual practice is material, social and semiotic; and (3) information as lifelong education is disseminated and placed in various practices, so that learning for each individual has a different meaning [1].

The Tri center of education includes formal, non-formal and informal education as a forum for implementing lifelong learning. Through a lifelong learning program that starts at home during the Covid-19 pandemic, fathers and mothers can accompany children while learning from home. Lifelong education in early childhood begins with informal education. The first and foremost education is informal education in the family. Both in large families and small families informal education has an important role.

Small Family is a small social group consisting of husband, wife and unmarried children. This small family is the smallest unit in society which is used as a place to carry out the social process. A small family consisting of two or more people, including father, mother and child in a situation of legal and religious marital ties [2].

A small family is said to be a social system. The social system as the carrying capacity of the conceptual framework includes: family integrity, personal well-being, child behavior and development, and opportunities for children and parents to 
play [3]. The elements in the social system include: the existence of feelings, goals, rules, position, roles and functions, levels, levels, rules, power, leadership, and facilities. The condition that arises in a small family when all social elements are applied, namely, the existence of trust. The formation of this small family is the will of the Almighty. Certain feelings in each family member may manifest feelings of mutual love, respect and jealousy for one another, especially among children because their social mental condition is not as stable.

Not only feelings, but also in a small family, having a common goal, both the goals of the parents and the collective goals of all the elements in the small family. All objectives that are formulated collectively will be realized by playing their respective functions. Thus, a family that has a comprehensive life goal can be realized. The family goals are the signposts in the development of a series of shared processes and the basis for triggering intra-family succession [4].

The small family is a place for the elements in it to carry out the socialization process. This socialization process includes several programs, both education, guidance and care. The socialization process in the family is interactional and relational between family members so that it allows children to understand emotional responses [5]. Maturity of family members starts from parents, both father and mother. Because the father and mother have gone through the period of forming their identity as independent individuals or what we call the adult condition. Parents have a level of maturity both in body and mind. Therefore, parents, both father and mother, have served wars and function as directors in a small family environment.

Not only parents who have roles and functions but also children as family members also have roles and functions in small families, namely understanding themselves to live and develop according to the child's development. In this condition, parents play the role of educators, mentors and nurses to provide stimulus in the child's development process. During the Covid-19 pandemic, the role of parents for low-income families was very risky for the continuity of children's education. Therefore, parents dedicate their energy and thoughts in encouraging effective parenting and learning from home [6].

This stimulus is carried out by parents in small families, but the development of children cannot be separated from the support from outside parties, namely the wider community. External environmental factors are supporting factors of the stimulus process carried out by parents. The environment outside contributes to the cognitive, social and emotional development of children [7]. The elements of society are broadly divided into the categories of formal and non-formal environments. The formal environment is an environment that is formed by the existence of certain rules that bind to each other the elements in it, for example, the school environment. Meanwhile, the next environment is a large family environment which we call the extended family. This extended family also has driving elements such as the family of the closest relatives, new community families and extended families. Family systems theory conceptualizes various forms of family in that the family is formed from extended families related to relatives, close families with individuals living together and communities [8]. So that the environment outside the nuclear family supports the socialization process in the nuclear family.

We often encounter parents giving trust to outsiders, namely the school. School is a place for children's education to assist the nuclear family in providing stimulus to children in order to support the child's growth and development process. Parents who give confidence to the school in providing stimulus and stimulation for children's growth starting from children in the womb, post-delivery, early childhood education, elementary schools, high schools and universities. The children have been escorted by their parents to school starting from 07.00 AM ending at school until 11.00 AM, 13.00 PM, 15.00 $\mathrm{PM}$ and at the college level according to a predetermined schedule. The implementation process runs smoothly in accordance with the expectations of the parents.

However, in reality at this time, parents and the school are faced with a condition that is different from the previous condition. This condition is what we know as the corona virus outbreak. The corona virus is believed by the public to be an epidemic that can attack the respiratory system. This virus causes the body's condition to get weaker and lack of immunity, so that many victims have died. 2019-nCov infection in humans can cause acute respiratory distress syndrome, and lead to death [9].

Parents and government officials feel anxiety, so that this condition is directly handled by various parties, both from the government and society in general. The government issued a policy quickly, so that the learning and teaching stimulus process for children that was previously carried out in school, now must be done online with the help of communication tools. This condition requires parents to accompany their children to study from home more by always coordinating with the school. In this condition, parents feel calm and happy because they have free time to always be with their children with the work from home program (BDR). The use of technology is the choice of parents as long as they accompany their children to learn from home. Online learning is effective in developed countries, but less effective in developing countries with limited signals and internet quotas [10].

But in terms of implementing the functions of the family unit, parents have their own challenges from this kind of condition. Parents are required to be able to implement parental functions as educators, mentors and nurses to the maximum in accordance with technological developments. In addition, the role of parents is to assist children, establish communication, provide supervision, nurture and motivation as well as effective learning $[6,11]$. However, parents feel that so far they have not been equipped with sufficient knowledge to become educators, nurses and mentors professionally. Professionally, the implementation of the three functions of care has not been carried out continuously and evenly in the amount of time. All 
this time, a mother is mostly at home and a father earns a living. This condition has been running for a long time and is believed by all elements in the small family. It is not uncommon for parents to think that the duty of care is carried out by a mother and father looking for sources of fulfillment in the form of a living.

Supposedly, the role of educator, mentor and care is not only carried out by a mother, but also by the father. The care of adolescents is different from the care of children. The method of parenting fathers to adolescents is more indulgent, while the method of parenting mothers at the age of children is more authoritarian [12]. Both have the same responsibility even though their roles are different. A mother demands that the father be able to provide the same parenting as the mother's portion. What a mother usually does, a father must also do. In fact it is not. Therefore, the results of this research suggest the role of a father in assisting children during the Covid-19 pandemic as a form of lifelong learning programs, both for parents and by their children.

\section{METHODS}

This study uses Mixed research methods design is a procedure for collecting, analyzing, and "mixing" quantitative and qualitative methods in a study or a series of studies to understand the research problem [13]. Through this mixed methods approach, the data collected can mutually reinforce both numbers and interview data. This research was conducted to find out about the actions taken by fathers in assisting children to learn from home as a form of application of the concept of lifelong learning. This research was conducted online in Indonesia with a questionnaire via google form totaling 110 respondents given the conditions during the Covid-19 period. The interview technique was carried out through online media, namely, google zoom media with the informants of this study, namely, fathers who have children with an age limit of 1-7 years. Researchers consider children aged 1-7 years require more intense mentoring than children who have entered the primary school to college levels.

The design of this study used an explanatory sequential design. "... Mixed methods might collect quantitative and qualitative information sequentially in two phases, with one data collection following and provide information on other forms of data collection" (figure 1) [14].

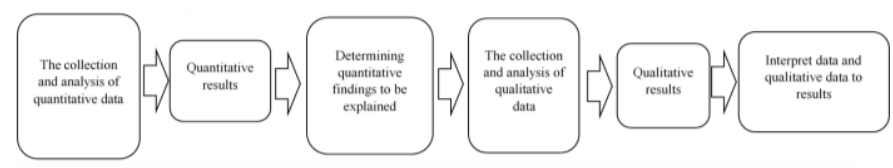

Fig. 1. Explanatory sequential design.

\section{FINDINGS AND DISCUSSION}

The implementation of lifelong education during the Covid19 pandemic for parents is quite a challenge. Fathers and mothers apart from having to work from the morning must also focus on children's education while studying from home. The father as the head of the family also has an important role in mentoring and caring for children. The focus of this study examines the role of fathers in assisting children during the Covid-19 pandemic. Of the 110 respondents, fathers ranging in age from 26 to 58 years, with marriage ages ranging from 6 years to 32 years. Fathers in assisting their children during the Covid-19 pandemic have varied times. The length of time a father has accompanied a child while studying during the Covid-19 pandemic can be seen in the figure 2 .

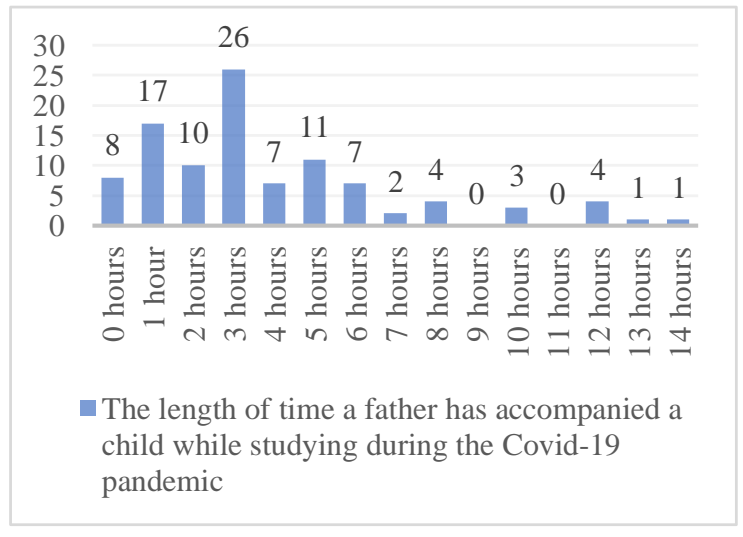

Fig. 2. The length of time a father has accompanied a child while studying during the Covid-19 pandemic.

During accompanying children to learn from home, the length of time that fathers accompany their children to learn has many variations in time. In this table, the father provides assistance to children from 0 hours to 14 hours. The average time for fathers to accompany their children to study is around 26 fathers with 3 hours/day, 17 fathers with 1 hour/day, 11 fathers with 5 hours/day, 10 fathers with 2 hours/day, 8 fathers with 0 hours/day, 7 fathers with 4 and 6 hours/day, 4 fathers with 8 and 12 hours/day, 2 fathers with 2 hours/day, and 1 father with 13 and 14 hours/day. The limited time for parents, especially fathers, in assisting children's learning during the Covid-19 pandemic is due to the busyness of the father working outside the home. In addition, there are fathers who have migrated to other provinces and their parents go to sea and come home from work too late.

The Covid-19 pandemic gives parents a lot of time at home, especially fathers who work from home, and virtually all activities. Covid-19 has a positive impact on families because the meeting between children and father and mother is more intense. The family function is increasingly functioning as a place for children's informal education. Parents become role models for children in their daily lives at home. Fathers are increasingly taking time to monitor children's health during the Covid-19 pandemic.

The research results describe the father's profession as the breadwinner of the family for a variety of fathers' jobs. Fathers as respondents in this study came from various educational and occupational backgrounds ranging from State Civil Servants 
(ASN), Honorary Teachers, private employees, fishermen, farmers, tailors, drivers, and entrepreneurs. Various professions and educational backgrounds also influence the pattern of parenting of fathers. Like a fisherman's son, because every night the father looks for fish in the sea, the father cannot accompany the child's study. Private employees who work shift systems with changing working hours make parents, especially fathers, have to share time with their children at home during the covid-19 pandemic. While the obstacle felt by parents, namely the father has limited competence in the child's learning assistance, but the demands of the parents want the child to get good grades.

The parenting style of parents who often spoil their children while together during the Covid-19 pandemic by using excessive smartphones, especially for playing online games. It makes the child more spoiled and uncontrollable, especially when all the wishes of the child are fulfilled by the father. The role of parents, namely mothers, also has an important role in controlling children's activities to suit the learning portion and using smartphones. The inculcation of basic religious values which is oriented towards the development of morals, knowledge, and environment and culture in children needs to be instilled from an early age. This is because all respondents have children.

Parents as primary educators at home or informal educators for children, the involvement of fathers in school also has an important role for children's development. The involvement of fathers in school is often underestimated by parents. This condition can be seen from the results of a questionnaire which illustrates that $50 \%$ of parents sometimes attend children's activities at school. Parents, especially dad, reasoned that they were busy with work, had a meeting, and were attending a webinar. Fathers always attend children's activities by $23.6 \%$ because parents, namely fathers, feel that they want to know about the child's development from school. As many as $26.4 \%$ of fathers do not attend children's activities at school. Parents are absent from children's activities at school on the grounds that the father is ashamed of going to school, does not feel comfortable going to school, and does not have the desire to come to school. Because mothers as guardians of students usually come more than fathers.

Children's education begins with imitating family members around them, especially parents. Informal education is a basic value for children to adapt to the outside world. Through the cultivation of religious values which are implemented by worshiping with family. The results showed that the father invited the children to worship together as much as $54.5 \%$; parents instill religious education. This concept is intended to provide a strengthening of the father figure as a leader in the family. As many as $42.7 \%$ of fathers sometimes invite their children to worship. This indicates that my father is too focused on work, so the inculcation of religious values is minimal. Meanwhile, $2.8 \%$ of fathers do not invite their children to worship because parents feel inadequate and do not have control over their children so that fathers cannot find a good way to invite children to worship.
Maintaining cleanliness, health of children and family members is the responsibility of the family together. Fathers, as role takers in child care and family care, are only natural in the covid-19 pandemic to prepare health facilities for example, $24.1 \%$ of children aged 4.5 years old, $11.1 \%$ of children aged 4 years, $13 \%$ of children aged 3.5 years, $6.5 \%$ of children aged 3 years, $7.4 \%$ of children aged 2.5 years, and $1.9 \%$ of children aged $<2$ years. By bathing the child, the parents, namely the father, directly provide education on how to keep the child's body clean. The collaboration between father and mother in providing health education to children is a manifestation of lifelong education.

From the research results, it is known that a father has a role as a caregiver. Fathers carry out the function of parenting by implementing roles as educators, mentors and nurses. The condition of the covid-19 outbreak is believed by parents, especially fathers, as a driving force for parents to always think positively, and consider this condition to have a beneficial impact. As for the positive lessons of Covid-19 for families, namely:

- From the intensity of the meeting between father and son, there is an increase in the quantity and quality of communication, both one-way, two-way and multi-way communication. Togetherness with other family members is more memorable and quality.

- In terms of education, parents are given a noble opportunity to implement the father's function as the main educator in the family. The conception of the father as breadwinner seems to be waning.

- In terms of mentoring, fathers are a source of examples and become a model or figure for children with various characteristics.

- In terms of care, fathers have the opportunity to always monitor the health condition of their children.

Some of the benefits brought about by covid-19, all of which are actually the main function of parents, especially a father. However, so far it has been neglected by the various reasons put forward to one another. The role of fathers is greater in involvement with sons than daughters [15]. Regardless of gender composition, the presence of boys attracts fathers to become active parents.

From the results of the interview, it is known that from the total of all respondents, $26 \%$ stated that 3 hours per day, a father accompanies a child while studying from home. In addition, $17 \%$ of fathers assist 1 hour per day, $11 \%$ of fathers assist about 5 hours per day, $10 \%$ of fathers assist 2 hours per day, and the rest are fathers without accompanying children's studies. And there was also someone who was there for more than 12 hours but without father control. Father's parents have various reasons why they have not spent more time in the mentoring period. Father's anxiety to become a better father leads to involvement of fathers in various parenting programs [16]. Most of them said that they were busy working. 
Work requires them to earn a living for survival. And most of them have a reason, namely, they are confused as to what action they should take. They have not been trained to act professionally like a teacher who has been trained to appear professional. Fathers as parents have an identity that determines how a child is cared for [17]. In carrying out parenting acts, a father cannot be separated from several obstacles that often occur. The obstacles are competitive, indulgent, indifferent, angry, protective and violent towards children [18]. Parenting barriers to competitive fathers. This means that there is a father who always wants his children to always be in the best position in his every action. And this was done by a father with various stimuli, often with violence if it does not achieve what the parents want.

The nature of pampering children is often done by a father. Because a father always feels guilty, for his absence in front of the children for a longer period of time. But a father thinks that giving all the wishes of the child and always fulfilling all the wishes of the child is the most powerful weapon to make amends. Parents shouldn't act that way. A father appears clearly in the children's life contributing to parenting activities [19]. A father's child has a different role and function from a mother. In this study, we found several roles that should be performed by parents, especially fathers. So that the barriers of father's parents can be overcome with various solutions.

Ecological based parenting principles, namely; oriented to the needs of children's growth and development, oriented to the development and application of value systems, morals, religion and culture, utilizing the environment as a source and learning content and carried out in a positive way to build closeness between people.

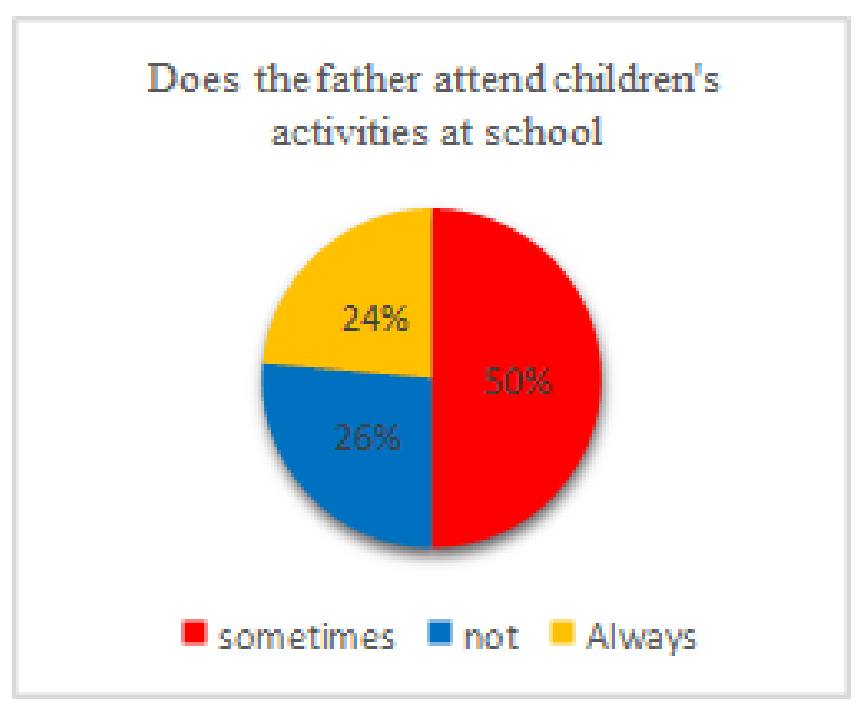

Fig. 3. Father's involvement in school.
Strengthening the role of the father during the pandemic in the field of education, namely, the father must be able to act as an educator. The involvement of fathers in attending to children's activities at school $23.6 \%$ always attended, $50 \%$ attended children's activities sometimes, and $26.4 \%$ did not attend school children's activities (figure 3). From the data above, it is known that a father is rarely involved in children's school activities. This is a challenge in itself for father. Fathers planned, implemented and evaluated. Fathers can take action to fulfill physical needs in planning children's learning. Parents, fathers, mothers, and children design planning for procurement of learning items. The involvement of children in learning design through planning, implementing, and evaluating learning activity programs is an important value in the child's learning process [20]. Fathers involve children directly, namely by involving children to directly participate in buying various learning needs. From there the closeness between father and son occurs. Father can provide education while traveling with learning resources related to the facilities to be purchased.

Fathers teach related to social actions outside the nuclear family. Fathers can maintain a child's curiosity, by preparing various methods to always stimulate children to ask about something new. A father must prepare an assessment instrument for child development. This is done by collaborating with schools such as the support of volunteers, children, parents, and schools in preparing multicultural education as an interactive group [21]. The school will provide signs for fathers in determining indicators of achievement of children's development according to their age.

The assessment material made by the father's parents was carried out by a mother. The mother assesses the child's development, and the father is in charge of monitoring the extent of the child's development. Before preparing assessment guidelines for children, parents and mothers are obliged to increase their knowledge regarding what are the indicators of children's development according to their stage of development. Parents have a big influence on children's performance at school, if they are involved in children's education, and monitor children's work after school [22]. As an educator, a father must be able to position himself to act as a role model, and a friend, but explain the limits to the child with their respective roles. Even though the children still look small, their capturing memory is functioning optimally according to its purpose.

A father must always provide various challenges in reaching the stages of development that have been designed. And fathers must always provide enlightenment in fostering children's interest in dreaming, pursuing a dream. Let the children express their dreams and be well documented. One day the dream will be discussed in accordance with the efforts that have been made. 


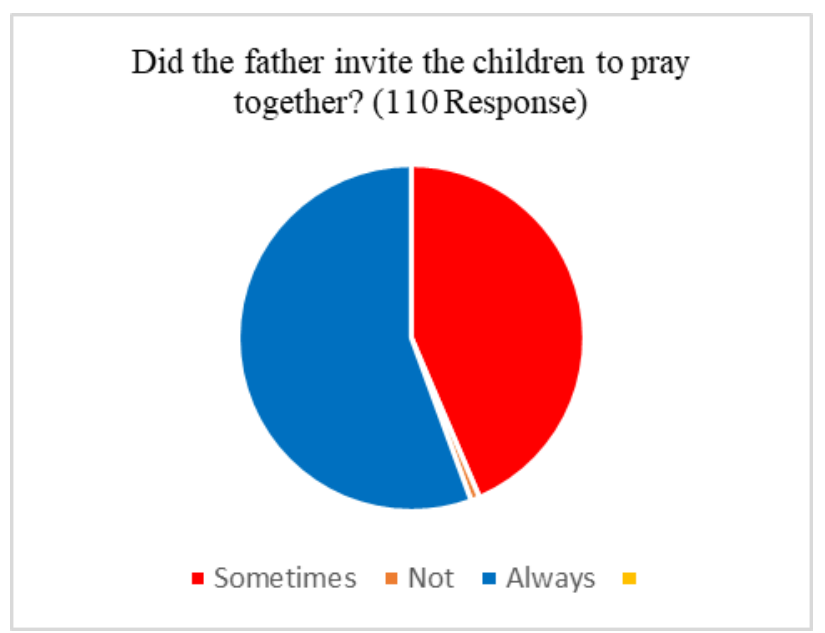

Fig. 4. Father invites children to worship togeter.

Figure 4 illustrates that fathers inviting children to worship together, $54.5 \%$ always invites, $42.7 \%$ sometimes, and $2.8 \%$ do not invite children to pray. From this data, it can be concluded that the father is a role model and figure in the nuclear family. The involvement of parents, especially fathers in the child's life, is to strengthen the child's behavior and emotional investment [15]. This is done by the father by inviting the children to worship together. However, most of these activities have not been carried out by the father to the fullest.

As a guide, a father can get close to and get to know the world of children. The more fathers know the world of their children, the wider the door will open for fathers to be more intense in communicating and having a connection with them. Although there is a view that the father has a temporal involvement in parenting [23]. Along with development, the father can find out the various preferences of the children, what they hates, their close friends, both at home and in the school environment. All information extracted from children must be well documented and not only stored, but the father must understand and always remember this.

When children ask questions about this, don't let the father not be able to answer and make the child's confidence level decrease. Avoid asking about something he/she has already explained. Act like a more professional than the child. A father can find out his/her talents and potential by consulting with a counselor or psychologist.

As a nurse, a father has the role of preparing health facilities, both for personal children and for public facilities used at home [24]. Fathers always monitor children's health conditions, bathe children and participate in eating activities together [25]. From the data above, it is known that most of the fathers' parents still bathe their children at the age of 4.5 years. If the child is 3 years old, the memory sensor will be sharper. Hence, at age, the father does not bathe the child if the child is a girl, but instead leaves the next responsibility to the mother. If the child is a boy, then the father bathes him, not the mother.
The characters inherent in a father are; responsibility, dignity, assertiveness, social attitude, discipline, empathy and sympathy. Teach the child responsibilities, through several assignments that are done regularly [26]. This activity is carried out by monitoring and evaluation. For example, there is a division of tasks at home. Fathers must always start to always be on time, and apologize if they do not comply with the rules that have been made and agreed upon collectively. Discipline must be exemplified by the father's parents first.

My father's job during the pandemic is to know about technology development, especially the digital world. Because the father must make wise rules regarding its use and designation. Fathers are involved and supervise children's activities on social media. Father actively provides understanding, restrictions, what is good and what is less profitable in the internet.

The difference in the function of father and mother, namely:

- Fathers can discipline children with various rules that have been agreed upon by all members in the nuclear family. Meanwhile, a mother implements the rules and reports her progress to the father.

- Father teaches about social life in the midst of a large family or community, and mother teaches about emotions to children.

- Fathers encourage children to continue to hone their abilities, encourage their children always to be brave to try about something new. Meanwhile the mother gave consideration according to the existing conditions.

\section{CONCLUSION}

The conclusion in this study is that a father has a role and responsibility as a caregiver. Assisting children to learn while at home with a minimum of 3 hours of learning every day is an example of children in implementing learning from home in accordance with the conditions of the Covid-19 pandemic. Effective parenting is by using a smartphone according to the portion and parental supervision. Parenting actions are divided into three categories such as education, mentoring and care. Educational action starts from planning, implementation and evaluation. Meanwhile, guidance is carried out by providing stimulation to stimulate children's growth and having skills along with development [27]. Treatment activities are adjusted to basic health measures and adopt a clean and healthy lifestyle.

\section{REFERENCES}

[1] R. Usher and R. Edwards, Lifelong learning-signs, discourses, practices, vol. 8. Springer Science \& Business Media, 2007.

[2] E. Sulistiono, M. Mustakim, and E. Yambeyabdi, "The Struggle Of Single Parent: Pattern Of Parenting In The Nuclear Family," Pancar. Pendidik., vol. 6, no. 4, pp. 81-92, 2017. 
[3] C.J. Dunst and C.M. Trivette, "Mediating influences of social support: Personal, family, and child outcomes,” Am. J. Ment. Defic., vol. 90, no. 4, pp. 403-417, 1986.

[4] J. Kotlar and A. De Massis, "Goal setting in family firms: Goal diversity, social interactions, and collective commitment to familycentered goals," Entrep. Theory Pract., vol. 37, no. 6, pp. 1263-1288, 2013.

[5] C. Abidin, "\#Familygoals: Family influencers, calibrated amateurism, and justifying young digital labor," Soc. Media Soc., vol. 3, no. 2, 2017.

[6] M. Ingram, R.B. Wolfe, and J.M. Lieberman, "The Role of Parents in At-Risk Populations," no. 2002, pp. 479-497, 2015.

[7] R.H. Bradley, B.M. Caldwell, S.L. Rock, H.M. Hamrick, and P. Harris, "Home Observation for Measurement of the Environment: Development of a Home Inventory for use with families having children 6 to 10 years old," Contemp. Educ. Psychol., vol. 13, no. 1, pp. 58-71, 1988.

[8] V. Jacobsen, L. Fursman, J. Bryant, M. Claridge, and B. Jensen, "Theories of the family and policy," New Zeal. Treas. Work. Pap. 04/02, p. 104, 2004

[9] N. Chen, M. Zhou, X. Dong, J. Qu, F. Gong, Y. Han, Y. Qiu, J. Wang, Y. Liu, Y. Wei, J. Xia, T. Yu, X. Zhang, and L. Zhang, "Epidemiological and clinical characteristics of 99 cases of 2019 novel coronavirus pneumonia in Wuhan, China: a descriptive study," Lancet, vol. 395, no. 10223, pp. 507-513, 2020.

[10] M. Adnan and K. Anwar, "Online learning amid the COVID-19 pandemic: Students' perspectives,” J. Pedagog. Sociol. Psychol., vol. 2, no. 1, pp. 2-8, 2020.

[11] W. Yulianingsih and R. Nugroho, "Keterlibatan Orangtua dalam Pendampingan Belajar Anak selama Masa Pandemi Covid-19," vol. 5, no. 2, pp. 1138-1150, 2021.

[12] L.G. Simons and R.D. Conger, "Linking mother-father differences in parenting to a typology of family parenting styles and adolescent outcomes," J. Fam. Issues, vol. 28, no. 2, pp. 212-241, 2007.

[13] J.W. and J.D.C. Creswell, Qualitative, Quantitative, and Mixed Methods Research Designs. California: Sage Publications, Inc., 2018.

[14] J. Creswell, "Research Design Qualitative, Quantitative, and Mixed Methods Approaches." SAGE Publications, Inc, New York, 2013.

[15] K.M. Harris and S.P. Morgan, "Fathers, Sons, and Daughters: Differential Paternal Involvement in Parenting," J. Marriage Fam., vol. 53, no. 3, p. 531, 1991.
[16] K.J. Daly, L. Ashbourne, and J.L. Brown, "Fathers' perceptions of children's influence: Implications for involvement," Ann. Am. Acad. Pol. Soc. Sci., vol. 624, no. 1, pp. 61-77, 2009.

[17] B.A. MCBRIDE, S.J. SCHOPPE, and R. R, "Child Characteristics Parenting Stress and Parental," J. Marriage Fam., vol. 64, no. November, pp. 998-1011, 2002.

[18] K.B. Guzzo, "New Fathers' Experiences with Their Own Fathers and Attitudes Toward Fathering," Father. A J. Theory, Res. Pract. about Men as Father., vol. 9, no. 3, pp. 268-290, 2011

[19] S. Istiyati, R. Nuzuliana, and M. Shalihah, "Gambaran Peran Ayah dalam Pengasuhan The Discription Of Father' s Role In Caring The Children," Profesi, vol. 17, no. 2, pp. 12-19, 2020.

[20] J. Leinonen and T. Venninen, "Designing Learning Experiences Together with Children," Procedia - Soc. Behav. Sci., vol. 45, pp. 466-474, 2012.

[21] M. Ojala, "An Inclusive Approach for Developing Multicultural ECE," vol. 4, no. 1, pp. 13-22, 2011.

[22] A. Kordi and R. Baharudin, "Parenting Attitude and Style and Its Effect on Children's School Achievements," Int. J. Psychol. Stud. vol. 2, no. 2, 2010.

[23] B.A. McBride, G.L. Brown, K.K. Bost, N. Shin, B. Vaughn, and B. Korth, "Paternal identity, maternal gatekeeping, and father involvement," Fam. Relat., vol. 54, no. 3, pp. 360-372, 2005.

[24] M.M. Feenstra, I. Nilsson, and D.B. Danbjørg, "“Dad - a practical guy in the shadow': Fathers' experiences of their paternal role as a father during early discharge after birth and readmission of their newborns," Sex. Reprod. Healthc., vol. 15, pp. 62-68, 2018.

[25] H.M. Kelly-Trombley, D. Bartels, and E. Wieling, “She's my baby' How recently incarcerated fathers experience their relationship with their daughters," Fathering, vol. 12, no. 1, pp. 94-114, 2014.

[26] E. Jansen, H. Harris, and T. Rossi, "Fathers' Perceptions of Their Role in Family Mealtimes: A Grounded Theory Study," J. Nutr. Educ. Behav., vol. 52, no. 1, pp. 45-54, 2020.

[27] T. Miller, “'It's a Triangle That's Difficult to Square': Men's Intentions and Practices around Caring, Work and First-Time Fatherhood," Father. A J. Theory, Res. Pract. about Men as Father., vol. 8, no. 3, pp. 362-378, 2010 . 